\title{
Study on the Training Mode of Professional Competence in the Practice Platform of Accounting Studio*
}

\author{
Chunling Shao \\ School of Economics and Management \\ Yiwu Industrial \& Commercial College \\ Yiwu, China
}

\begin{abstract}
Based on the empirical analysis method of the accounting studio project, the mode of practice platform of the accounting studio is constructed from the point of view of combination of learning with working of college-enterprise. On this basis, the paper draws some conclusions some conclusions of long-term mechanism for developing professional competence and put forward related suggestions.
\end{abstract}

Keywords-accounting studio; practice platform; training of professional competence

\section{INTRODUCTION}

Developing students' vocational competence is the goal of vocational education which is required to develop applied talents with high adaptability and quality for the society. During the transformation and upgrading of China's economic construction, the functions for corporate accountants are required to be upgraded accordingly. That is, the talents required by the occupational area have shifted from stewardtype talents based on traditional "bookkeeping, accounting and account reporting " toward the administrative talents who have the ability to analyze, use and participate in decision-making based on handling and proving information [1]. With the strengthening of the accounting post functions in the new era, accountants are faced with new challenges and opportunities, who are required not only to master basic skills in accounting treatment of basic operating skills, but also to have professional ethics and comprehensive professional competence in adjustment to circumstances, stress tolerance, communication, innovation consciousness and team cooperation, etc. Therefore, it is hared to achieve the goal of developing accountant talents with comprehensive vocational ability only depending on theoretical teaching in class and software and handwork simulation training in the training room, and only putting students in real professional environment, can they combine what they learned in class with actual account handling and accumulate work experience from all aspects so as to develop their comprehensive vocational ability in an effective way.

*2017 Key subject of Zhejiang Society of Vocational and Technical Education (ZD17018); 2018 Research Project of Zhejiang Federation of Social Science Circles (2018N62)

\section{EXISTING PROBLEMS}

\section{A. Lack of Integrated Training of Professional Skills}

From observing the current professional talent training schemes, we can see that professional ability and post skill knowledge is divided and arranged in different classes, so the training of skills is realized through different classes and training projects, which is inevitable to cause a separation. In addition, due to the cognition limitation of students, it is difficult for them to get a clear recognition of the vocational ability developing goals of different professional courses, and as a result, it is hard for students to apply knowledge and professional skills they acquired to the post practice consciously to the work practice, thus causing disconnection of the talent training of colleges from social needs. Thus, it is a key problem to how to improve the problems of fragmentation and de-contextualization of continuous work of students' vocational competence caused by dispersed learning of specialized courses to improve the quality of developing talents.

\section{B. Lack of Integrated Professional Practice System}

Due to the particularity of enterprise accounting post, it is hard for the external personnel to get access to the accounting data of the enterprise. In addition, owing to limited number of accounting posts set in an enterprise, the enterprise requires the accounting personnel not as much as labor intensive employment units such as production management department of basic level or marketing department, so it cannot meet the requirements of hundreds of accounting majors for practice and training at fixed post regularly. At present, in most of higher vocational colleges, the practice part of specialized courses for accounting majors is basically arranged in the training room of the college, where students practice their accounting skills item by item with the help of some software tools such as "Nets-within-Nets" and "Tax Friends", and they barely come into contact with integrated practical training in the upstream and downstream posts and post groups, so the college fails to provide systematic, scientific and threedimensional integrated training of professional knowledge, skills and innovation for students. In the meantime, due to lack of overall planning, the constitute factors of the training room 
is not completed and cannot support all-dimensional, comprehensive and layered practical teaching; the practical materials are separated and isolated from each other, so it is hard to integrate the materials and make effective allocation of the practice and training resources; the hard and soft conditions are out of touch with the actual post environment, so it is can only meet the practice requirements in cognitive dimension and course practice level and cannot provide comprehensive, systematic and integrated practice and training based on the characteristics of the post. As a result, it is difficult for students to experience the practice of vocational competence and professional quality required by the real enterprise posts.

\section{Lack of Effective Platform for the Teaching Staff to Improve the Practice Guidance Level}

At present, the faculty in higher vocational colleges is mainly composed of postgraduate students of the current years, with some of returnee masters, who are lack of enterprise practical experience. In the qualification evaluation of "double-qualification teachers", the colleges, generally, only require to provide related document of visiting work in post of an enterprise, or related middle-level skill certificate, and will not strictly examine the occupational qualities and hands-on abilities of the candidates. As the higher vocational college teachers have to undertake the work of scientific research, thesis supervision, compiling textbook, head teacher, etc., they are under great stress of heavy teaching task, teaching reform and scientific research, so it is difficult for them to spare long time to conduct comprehensive and systematic post practice in an enterprise. In addition, due to the particularity of accounting post, the teachers cannot obtain too many short-term work opportunities on regular post from local enterprises, and so they lack effective platform to improve their ability to guide the practice.

\section{Lack of Effective Evaluation System of Comprehensive Practice}

The evaluation system of practical activities is different from that of theoretical courses, so the practice effect of students cannot be determined through examinations. At the present stage, still based on the final evaluation of knowledge, the assessment of practical teaching in higher educational colleges places emphasis on the final results students obtain in the practice such as certificate, accounting book, statement, summary report, etc., but neglects or overlooks the developing of professional quality during the practical operation. It is common for students to plagiarize each other's homework or download form the internet, so it cannot reach the expected goal of practical teaching and satisfactory practice effect.

Abiding by the method of developing the combination of learning with working project, the accounting studio closely cooperates with local accounting firms and introduces real accounting cases, so that the teachers and students can set up several groups to conduct accounting treatment of the business transactions of different enterprises. The accounting studio takes the project as the carrier of practice, so that students can fully experience the typical work tasks of the accounting post during completing the projects, and also can make a deep understanding the requirements of the post for theoretical and practical knowledge. At the same time, students are required to make plan and comprehensive arrangement, implement, and give feedback in addition to thinking and analyzing to effectively promote the comprehensive vocational ability of the students. Therefore, the accounting studio uses the practice platform project to drive the talent training and adopts the action-oriented teaching integrating teaching, learning and practicing, which can effectively integrate into the developing of vocational competence of accounting majors.

\section{LITERATURE REVIEW}

Accounting vocational competence refers to the comprehensive professional ability required by accounting personnel to complete a series of accounting activities, containing the knowledge, quality, skills and attitude toward work of accounting personnel. However, it is definitely not possible for teachers to help students acquire such ability only by giving them part of independent courses, but it requires combination of in-class courses and out-class practice, and integration of theory and practice so as to comprehensively develop students' professional knowledge, quality, skills and personal virtue in daily life. The vocational competence structure proposed by German vocational competence development and research theory based on dynamic occupational development view is characterized by integrity, comprehensiveness and openness. The basic structures of vocational competence include two dimensions-the longitudinal dimension and the horizontal dimension; thereinto, in the longitudinal dimension, the structure of vocational competence is composed of basic professional competence and comprehensive professional abilities that is key ability; in the horizontal dimension, the structure of vocational competence is composed of professional ability, methodological ability and social ability [2]. Many countries insist on integrate the developing of vocational competence into that of comprehensive ability, and the action-oriented teaching integrating teaching, learning and practicing.

For German higher educational accounting, with the core of the "dual system" and the essence of college-enterprise cooperation, it adopts practical teaching to develop highquality and high-skilled versatile talent needed by the enterprises; for Canadian higher educational accounting development system, it focuses on ability training, CBE for short, that is the colleges partly cooperate with the government to jointly establish practice base; at present, more than 30 countries have been learning to apply CBE teaching mode. In the early 20th century, Germany Bauhaus Design Institute abandoned its close-ended teaching mode and adopted openended teaching mode which takes projects as the barrier, combines practical production and strengthens the dynamic integration of teaching, learning and practicing, thus realizing the effective integration of theory and practice; the department of accounting of America University of Texas Austin adopted studio teaching mode based on college-enterprise cooperation. That is, the accounting studio through cooperation with the enterprises give specific accounting projects, and students set up several teams to practice and train their comprehensive vocational competence by utilizing these projects; Singapore Nanyang Technological University introduces "Teaching 
Factory" with an operation mode similar to factory to form a comprehensive practice mode integrating enterprise, teaching factory with college [3].

At present, most of modern Western design education adopts the studios system, which greatly in the western modern design education mostly adopts the studio system, which is greatly helpful in developing students' professional ability, practical ability and accumulating social resources.

Since the 1980s, some colleges in China have begun to try to use studio projects to enhance the developing of vocational competence. In 1984, the Guangzhou Academy of Fine Arts took the lead in reforming and established the White Horse Advertising, showing that the studio teaching mode was being formed and developed gradually in colleges of arts, design, etc. As the higher educational education requires close combination of teaching and practice, Shanghai Art and Design Academy, Shenzhen Polytechnic and other higher vocational colleges firstly tried to set up art and design studios. In Analysis of Contradictions in the Operation of Professional Advertising Studios and Its Technical Route Map Popular Literature, $\mathrm{Wu}$ Shenghua and $\mathrm{Hu}$ Guohua et al proposed a series of ideas about the thinking of establishing studio, studio operation mode, the possible problems during the operation and so on [4].

Since then, most of the research viewpoints of studio practical teaching have been focusing on "college-enterprise cooperation and combination of learning with working", etc., such as "using the studio to conduct effective practical is the foundation of realizing combination of learning with working", "the studio is helpful in developing "double-qualification teachers, quality of the teaching staff and students' adaptability and employability" etc [5].

By straightening out of the research about accounting studio, we find that more and more experts and scholars in the field of accounting pay close attention to studio mode. For example, Fei Linqi, et al of Liaoning Agricultural Technical College firstly tried to set up "Huicheng Accounting Studio" by cooperating with ten more local accounting firms to create a practice platform that can reflect real atmosphere and scenario of accounting post [6]. Wan Yan proposed the idea of flexible educational system which mainly includes converting students' work performance in the studio, the task amount completed and achievement into credits, and also explored the organization structure, operation mechanism and talent development mode of the studio that imitates the enterprise.

In conclusion, the research on studio teaching mode in China mainly focuses on the design and art majors. In addition, the practical teaching mode is still in the initial stage and lacks systematic and in-depth research, let alone forms a universal system theory of operation mode of the comprehensive studio practice platform, thus requiring further improvement in practice.

\section{RESEARCH APPROACH}

Based on the method of developing the combination of learning with working project, this research introduces real business transaction cases of enterprises and establishes authentic accounting work environment to provide students with a practical training place integrating teaching, learning and practicing. In addition, the research aims to regard the studio projects as carrier to construct action-oriented teaching mode integrating with developing professional accounting competence so as to develop the comprehensive vocational competence. "Fig. 1" shows the operation frame model of the studio.

By cooperating with enterprises, accounting firms and certified tax agencies, the studio sets up a enterprise-style management framework, introduces the basic process of handling accounting events and adopts the practical teaching mode in line with the enterprises. Through operation of studio projects, development of comprehensive vocational competence is expected to be realized. Based on integration of teaching, learning and practicing, the students can use the comprehensive accounting vocational skills to complete multiple tasks through work shift in different sectors, and then design the training of accounting professional ability (industrial and commercial tax registration, accounting design, subject setting, establishment of account set, cashier operation, account handling, cost calculation, property verification, error checking, disposal of computerized accounting, accounting software system maintenance, tax declaration, business annual inspection, information sorting and analysis, professional ethics, lifelong learning, etc.) so as to realize the integrated development of accounting vocational competence through the practice link in the project operation.

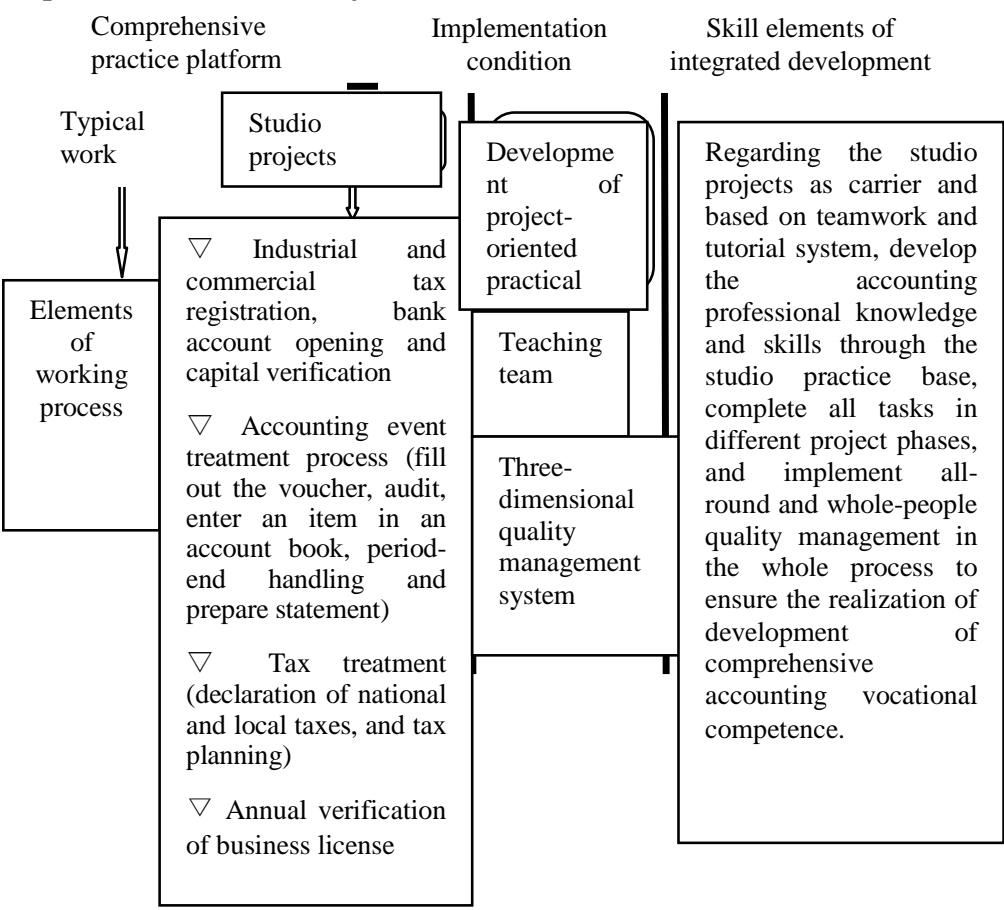

Fig. 1. Model of studio practice platform.

This research adopted the investigation and analysis method combining with other research methods such as quantitative and qualitative analysis and empirical research, and we obtained visual data by consulting literature and investigation materials to reveal the professional ability of the 
higher vocational accounting, the ability developing mode, as well as the establishment, operation and management mode of accounting studio in higher educational colleges; based on this, from the analysis point of view of college-enterprise combination of learning with working, and from the development level of accounting studio, the research explores the strategy on developing comprehensive accounting professional ability and the corresponding meaning, in addition to exploring the long-term talent development mechanism driven by the accounting studio project.

\section{RESEARCH CONCLUSIONS AND DISCUSSIONS}

\section{A. Connotation Definition of Professional Competence}

In line with the summary through the investigation of the industry and enterprise units, the senior accounting students are required to have the following occupational abilities for the post of accounting studio.

TABLE I. OCCUPATIONAL ABILITIES FOR THE POST OF ACCOUNTING STUDIO

\begin{tabular}{|c|c|c|}
\hline $\begin{array}{c}\text { Categ } \\
\text { ory }\end{array}$ & $\begin{array}{l}\text { Leadership } \\
\text { Program }\end{array}$ & Post Professional Competence \\
\hline \multirow{6}{*}{$\begin{array}{l}\text { Basic } \\
\text { profes } \\
\text { sional } \\
\text { compe } \\
\text { tence }\end{array}$} & $\begin{array}{l}\text { Accounting } \\
\text { judgmentability }\end{array}$ & $\begin{array}{l}\text { Be able to effectively determine economic } \\
\text { business matters }\end{array}$ \\
\hline & $\begin{array}{l}\text { Accounting } \\
\text { ability }\end{array}$ & $\begin{array}{l}\text { To do the real legal complete bookkeeping, } \\
\text { accounts and reimbursement for economic } \\
\text { business }\end{array}$ \\
\hline & $\begin{array}{l}\text { Accounting } \\
\text { supervision } \\
\text { ability }\end{array}$ & $\begin{array}{l}\text { In accordance with the accounting law and } \\
\text { the financial and economic laws and } \\
\text { regulations, to make the supervision before } \\
\text { the event, at present and after the event } \\
\text { against the legitimacy, authenticity and } \\
\text { rationality of the economic activities of } \\
\text { state organs and enterprises. }\end{array}$ \\
\hline & $\begin{array}{l}\text { Accounting } \\
\text { analysis ability }\end{array}$ & $\begin{array}{l}\text { Be able to analyze the financial situation, } \\
\text { operating results and cash flow of the } \\
\text { enterprise. }\end{array}$ \\
\hline & $\begin{array}{l}\text { Software } \\
\text { operation ability }\end{array}$ & $\begin{array}{l}\text { Be able to operate and maintain the } \\
\text { accounting software skillfully }\end{array}$ \\
\hline & $\begin{array}{l}\text { Accounting } \\
\text { forecasting and } \\
\text { decision- } \\
\text { making ability }\end{array}$ & $\begin{array}{l}\text { According to the historical data of the } \\
\text { enterprise for years, use a professional } \\
\text { method to make a relatively scientific and } \\
\text { credible forecast for the future business } \\
\text { activities of the enterprise and the reference } \\
\text { for decision making of enterprise } \\
\text { management }\end{array}$ \\
\hline \multirow{5}{*}{$\begin{array}{l}\text { Compr } \\
\text { ehensi } \\
\text { ve } \\
\text { profes } \\
\text { sional } \\
\text { abilitie } \\
\text { s }\end{array}$} & $\begin{array}{l}\text { Sustainable } \\
\text { learning } \\
\text { abilities }\end{array}$ & $\begin{array}{l}\text { Be able to all kinds of resources for } \\
\text { learning new ideas and technologies, and } \\
\text { updating knowledge and skills of finance } \\
\text { and taxation in time }\end{array}$ \\
\hline & $\begin{array}{l}\text { Information } \\
\text { processing } \\
\text { capability }\end{array}$ & $\begin{array}{l}\text { To make an analysis and processing of } \\
\text { accounting information data }\end{array}$ \\
\hline & $\begin{array}{l}\text { Communication } \\
\text { cooperation, } \\
\text { organization } \\
\text { and } \\
\text { coordination } \\
\text { skills }\end{array}$ & $\begin{array}{l}\text { Be able to do the effective communication, } \\
\text { organization, execution, coordination and } \\
\text { feedback. }\end{array}$ \\
\hline & $\begin{array}{l}\text { Problem- } \\
\text { solving } \\
\text { capability }\end{array}$ & $\begin{array}{l}\text { To put forward a feasible solution for the } \\
\text { problems existing in the enterprise }\end{array}$ \\
\hline & $\begin{array}{l}\text { Contingency } \\
\text { and innovation } \\
\text { ability }\end{array}$ & $\begin{array}{l}\text { Be able to deal with accounting events, } \\
\text { special businesses and emergencies in the } \\
\text { new normal economic environment }\end{array}$ \\
\hline
\end{tabular}

\section{B. Establishment of Education Platformoperation Mode of Accounting's Professional Comprehensiveability}

Relying on the finance and accounting professional resources, the entrepreneurship and innovation studio shall be established to dock the leading enterprises in the local industry, such as Zhicheng Accounting Firm, Jinqiao Tax Accountant Firm, Shengye Accounting Firm, whose businesses are development of agent accounting business, enterprise audit subproject, business registration, annual inspection and alteration. The studio has dual attributes of students' practice teaching and external business. Based on the specific projects of real customers, it is a good practice teaching platform for students.

The studio has introduced the enterprise management pattern and basic accounting process, so as to achieve substantive cooperation between the schools and enterprises. After the students finished the professional courses, they are divided into batches and groups to enter the studio as expectant employees, and then conduct the practice of professional comprehensive skills. The entry of the students into the studio means entering the business and entering the real job. The teacher is involved in the management as a financial and accounting supervisor. A group of 3-5 students in the studio undertakes the accounting, audit and closing of accounts an enterprise. According to the local main industry, the internship programs in the studio are divided into manufacturing industry, E-commerce, logistics industry and foreign trade service industry. According to the categories, the students shall work as the work shift and practice as groups, and the internship period of each category is one month. And they shall carry out comprehensive practice of accounting treatment in multiple industries by stages. In order to ensure the correct handling of the accounts, the studio adopts a multi-level and multi-layer audit system. And the members of each group are audited by role, reviewed by the group leader, finally checked by the studio tutor, and examined and verified by the enterprise tutor.

The studio shall establish direct relationship with enterprises. When entering the studio, the students have the dual identity of students and employees, who completed not only the training task but also the business project of the studio. The professional practice teaching is directly docked to professional posts, from which the students have obtained a relatively stable training base. And the real enterprise project also makes students more interest in learning and entrepreneurship, which can effectively motivate students' desire for learning, and improve the students' professional ability.

\section{Practice Course Development of Studio Project Orientation}

Based on the idea and method following the curriculum development of engineering integrated project, we shall analyze the financial activity process, decompose the factors of work process and combine the professional skills module to design the learning task. The financial activity process shall be decomposed to the four working processes of "Industrial and commercial tax registration, accounting business process, tax handling, and business license annual audit". And the four processes shall include accounting professional knowledge, 
skill and accomplishment (industrial and commercial tax registration, accounting design, subject setting, establishment of account set, cashier operation, account handling, cost calculation, property verification, error checking, disposal of computerized accounting, accounting software system maintenance, tax declaration, business annual inspection, information sorting and analysis, professional ethics, lifelong learning, etc.). We shall setup specific sub projects (tasks), take tasks as the carriers, project driving as the guidance, and make teaching as a whole.

Taking the working process as the guide and emphasizing the professional ability, the studio practice course shall form a reasonable and scientific practice system of higher vocational accounting profession. The vocational competence training butted by the workroom is shown in "Table II".

TABLE II. BUtTING SHEETS OF VocATIONAL COMPETENCE TRAINING OF WORK TASKS

\begin{tabular}{|c|c|c|c|}
\hline Subitem & $\begin{array}{c}\text { Vocational } \\
\text { Ability } \\
\end{array}$ & Nature of Abilities & Work Task \\
\hline \multirow{3}{*}{$\begin{array}{l}\text { Profession } \\
\text { al quality }\end{array}$} & $\begin{array}{l}\text { Work } \\
\text { values }\end{array}$ & $\begin{array}{l}\text { Correct work values } \\
\text { and attitude }\end{array}$ & $\begin{array}{l}\text { Property inspection, } \\
\text { error checking and tax } \\
\text { declaration. }\end{array}$ \\
\hline & $\begin{array}{l}\text { Basic } \\
\text { ability }\end{array}$ & $\begin{array}{l}\text { Physical and mental } \\
\text { health, analytical } \\
\text { processing ability } \\
\text { and information skill } \\
\text { ability }\end{array}$ & $\begin{array}{l}\text { Information } \\
\text { organization and } \\
\text { analysis and accounting } \\
\text { and office software } \\
\text { application operation }\end{array}$ \\
\hline & Key ability & $\begin{array}{l}\text { organization and } \\
\text { coordination ability, } \\
\text { emergency response } \\
\text { capacity, individual } \\
\text { expanding capacity } \\
\text { of continuous } \\
\text { learning }\end{array}$ & $\begin{array}{l}\text { Small group } \\
\text { cooperation, business } \\
\text { tax registration, } \\
\text { industrial and } \\
\text { commercial annual } \\
\text { inspection and new } \\
\text { economic technology }\end{array}$ \\
\hline \multirow{6}{*}{$\begin{array}{l}\text { Vocational } \\
\text { ability }\end{array}$} & \multirow{6}{*}{$\begin{array}{l}\text { Professiona } \\
1 \text { ability }\end{array}$} & $\begin{array}{l}\text { Professional basic } \\
\text { knowledge, business } \\
\text { confirmation, } \\
\text { making } \\
\text { certificates, } \\
\text { registration book } \\
\text { and preparing } \\
\text { financial statement }\end{array}$ & $\begin{array}{lr}\text { Accounting } & \begin{array}{r}\text { design, } \\
\text { subject }\end{array} \\
\text { opening, } \\
\text { accounting } & \begin{array}{r}\text { treatment } \\
\text { and }\end{array} \\
\text { statement }\end{array}$ \\
\hline & & funds management & Cashier operation \\
\hline & & $\begin{array}{ll}\text { output } & \text { cost } \\
\text { accounting } & \end{array}$ & cost account \\
\hline & & $\begin{array}{l}\text { Handling of tax and } \\
\text { fee business }\end{array}$ & tax declaration \\
\hline & & $\begin{array}{ll}\text { Economic and } \\
\text { business audit }\end{array}$ & $\begin{array}{l}\text { Voucher audit, capital } \\
\text { audit. }\end{array}$ \\
\hline & & $\begin{array}{l}\text { Application of } \\
\text { finance and } \\
\text { accounting software }\end{array}$ & $\begin{array}{l}\text { Establishment of } \\
\text { account } \\
\text { computerization } \\
\text { processing and } \\
\text { accounting software } \\
\text { system maintenance }\end{array}$ \\
\hline
\end{tabular}

\section{Teaching Staff Construction}

For an integrated part of studio and teaching, and project driven mode, there is a relatively high demand to the tutors that they shall bear the teaching instruction of students' practice. For example, under the environment of new fiscal and tax reform, they shall correctly carry out economic business accounting treatment, tax declaration, and industrial and commercial annual inspection. They are also responsible for the routine business management of the studio and the drafting and implementing of plan. They shall also master the idea and method of organizing team management, and the organization arrangement of the project. It is also necessary to have certain business development ability and comprehensive coordination ability. So, when building a studio teacher team, the enterprise technicians shall be encouraged to be deeply involved in studio teaching. The operation of studio project shall be participated and guided by the backbone personnel of the industry that we engage, such as the bank, tax department, enterprise, accounting firm and tax accountant agent. Finally the studio training program is transferred to the professional teaching project, and is forming a "double-qualification teachers" team of teachers with complementary and part-time jobs gradually in practice. And we will explore and further improve the practice and guidance level of professional teachers.

\section{E. Construction of Quality Management System of Three- dimensional Practical Activities}

Feigenbaum, an American managerialist, put forward the theory of Total Quality Management (TQM) in Total Quality Management in the 1960s. The theory's basic ideas can be summarized in the whole process, all-dimensional and all related personnel. In the quality management system of professional studio practice activities, in order to effectively overcome the subjectivity, randomness and formality that has always been shown in the quality management of practical teaching in Higher Vocational Colleges, it shall be handled through the whole process quality monitoring, all-around quality management methods and standards, quality participation and supervision of all staff, and the organic combination of dynamic and static supervision.

1) Strengthening the time dimension to realize the quality management of whole course practice activities: Driven by the studio project, the teaching practice time of the students is no longer limited to the classroom in the integrated professional ability training practice platform of "Teaching, doing and practice". Most of platforms extend to all time after class, including days of rest and holidays. It is very important to strengthen the quality monitoring system of the whole process practical activities of which the process recording feedback shall be strengthened. The relevant charts are clearly defined in the regulations of the studio system, and the charts shall be recorded, signed and checked regularly. A group as a unit, the members shall supervise each other by the upper and lower chain of operating process, and the supervision between groups shall be carried out by an equal chain. The tutor shall make real time guidance to practical tasks and make a good record of the process. There shall be summaries and reports feedback on the quality supervision system of the whole process activities.

2) Extending the spatial dimension to realize the quality management of all-dimensional practice activities: The studio comprehensive practice platform is extended extremely in teaching space. And the students' main teaching places are extended from classrooms and schools to enterprises, studios, 
banks and tax authorities. The professional teaching and research office, with the studio, formulates the management methods and systems of the students' comprehensive practice activities, which can standardize accounting treatment process, clarify the studio practice subject and the enterprise docking requirements, make regular statistics to the evaluation sheet of fiscal and tax treatment accuracy of practice projects, implement the student projects' customer satisfaction tracking system, and implement the quality management measures of practical activities in all directions.

3) Perfecting the main body dimension to realize the quality management of all-staff practice activities: A scientific and reasonable evaluation system of studio practice teaching, can fully mobilize the initiative and enthusiasm of the students to practice and study. We also make the introduction of multi-angle and diversified evaluation index, in which the subjects of evaluation include school tutors, enterprise tutors and practice students. Relying on the workplace environment of the accounting studio, the main evaluation basis is the implementation process and the actual benefits produced in the project. It shall be adopted that process assessment shall be combined with final assessment, and students' self-assessment shall be combined with team evaluation and teacher assessment. Finally, we will form a multi-dimensional assessment and evaluation performance by the integrative practical activities in studios, so as to promote the construction and management of the teacher-student team, and strengthen the self-management and promotion of students.

\section{CONCLUSION}

In the educational models of studio, the carrier is the project, and the guidance is students' comprehensive vocational ability training. Through the studio platform, the enterprises are moved into the campus, which can share the educational resources of schools and enterprises and integrate the comprehensive practice of professional practice, as well as improve the means of cultivating talents and establish a longterm mechanism for educating people. If we solve the contradiction between supply and demand of talent training and enterprise needs, we can effectively enhance the core competitiveness of the students and make education return to the essence of self perfection and development.

\section{REFERENCES}

[1] Kong Delan “Triple-double"Exploration of Accounting Personnel Mode [J]. Chinese Vocational and Technical Education. 2015(1).

[2] Hu Wei. Vocational Training of Higher Vocational College Students and Its Significance [J]. China Academic Journals, 2015(11).

[3] Wang Yan. Thoughts of Professional Building and Educational Reform Promoted by Accounting Studios [J]. Times Finance2016(4).

[4] Wu Shenghua, Hu Guohua. Analysis of Contradictions in the Operation of Professional Advertising Studios and Its Technical Route Map Popular Literature [J]. Management \& Technology of SME, 2012(3).

[5] Qin Weiyun. Study on Operation of Art Design Studios in Higher Vocational Colleges [D]. Master's thesis of Hunan Normal University, 2014(12).
[6] Fei Linqi. Teaching Model Research of Accountant Specialty in SchoolEnterprise Deep Cooperation Studios [J]. China Township Enterprises Accounting, 2017(1). 